\title{
PCR and in situ hybridization for the detection and localization of a new pathogen Francisella-like bacterium (FLB) in ornamental cichlids
}

\author{
Chia-Yu Hsieh ${ }^{1}$, Zong-Bing Wu ${ }^{2}$, Ming-Chen Tung ${ }^{1}$, Shinn-Shoung Tsai ${ }^{1,2, *}$ \\ ${ }^{1}$ Department of Veterinary Medicine and ${ }^{2}$ Southern Taiwan Aquatic Animal Disease Diagnostic Center, \\ National Pingtung University of Science and Technology, 1 Shen-hu Road, Neipu, Pingtung 912, Taiwan, ROC
}

\begin{abstract}
Archived formalin-fixed, paraffin-embedded tissues from 28 diseased ornamental cichlid fish associated with visceral granulomas were examined by polymerase chain reaction (PCR) and in situ hybridization (ISH) for detection of Francisella-like bacteria (FLB). The 16S rDNA FLB-specific primer pair 180f/465r was used on naturally infected ornamental cichlids, resulting in 11 positive cases (39\%). Using DNA probes, all 28 cases (100\%) showed a positive reaction, and most labeled cells were observed in the visceral granulomas of infected individuals. FLB was detected in cells morphologically resembling epithelioid and endothelioid macrophages. ISH was more sensitive than PCR or routine histopathological examination, based on the examination of archived formalin-fixed, paraffin-embedded tissues in this study. Furthermore, this technique located a new fish pathogen, FLB, in ornamental cichlids. The causative agent was similar to the pathogen inducing systemic granulomas in tilapia.
\end{abstract}

KEY WORDS: Francisella-like bacterium $\cdot$ FLB $\cdot$ PCR $\cdot$ In situ hybridization $\cdot$ Cichlid $\cdot$ Ornamental fish

\section{INTRODUCTION}

Between 1998 and 2002, 28 ornamental cichlid fish were naturally infected with an unknown intracellular coccobacillus that caused granulomatous lesions in the visceral organs. Attempts to culture the intracellular bacterium failed. Recently, a Francisella-like bacterium (FLB) has been reported to cause visceral granulomas in tilapia (Hsieh et al. 2006) and Atlantic cod Gadus morhua (Nylund et al. 2006, Olsen et al. 2006). On the basis of the clinical signs and the cytological, histopathological and ultrastructural characteristics, the infected ornamental cichlids had features similar to those of tilapia with FLB infection. However, the relationship between the FLB and the host lesions was uncertain and required investigation.

In situ hybridization (ISH) using digoxigenin (DIG)labeled oligonucleotide probes complementary to unique target sites on the 16S rRNA (rDNA) is a useful method for the detection and identification of micro- organisms (Bashir et al. 1994, Barrett et al. 1997, Kwon \& Chae 1999). Specific probes can be designed to locate organisms that cannot be cultured (Hayashi et al. 1990, Komminoth \& Werner 1997) or visualized by conventional methods, such as viruses (Lewis \& Wells 1992), Chlamydiae (Campbell et al. 1993) and Mycobacterium paratuberculosis (Hulten et al. 2000). In addition to identifying the pathogens, ISH is an increasingly popular tool for locating pathogenic organisms in their target tissues (Gebhart et al. 1994, Loy et al. 1996, Gencay 1997, Gumus et al. 1997, Jantos et al. 1999, Chae et al. 2002). The method is sufficiently sensitive that target nucleic acids can be detected in tissue sections using a light microscope and non-radioactively labeled probes (Brown 1998). A probe that binds to the FLB 16S rRNA sequence as well as to the genomic DNA sequence provides an invaluable tool to demonstrate FLB in tilapia (Hsieh et al. 2006).

We retrospectively studied archived samples (obtained from the Southern Taiwan Aquatic Animal 
Disease Diagnostic Center [STAADDC] and collected between 1998 and 2002) of ornamental fish with visceral granulomas for investigation of the causative agent. A DIG-labeled DNA probe specific for a novel FLB partial 16S rRNA gene (base pairs 180 to 485) was developed for localization of the agent in the infected tissues of ornamental fish. This is the first report concerning granulomatous disease in ornamental fish due to infection with FLB, and comparing the sensitivities of ISH, PCR and histopathological assays.

\section{MATERIALS AND METHODS}

Sampling. Twenty-eight diseased cichlid ornamental fish, consisting of 11 species: firebird Aulonocara rubescens, elegans Pseudotropheus elegans, zebra Pseudotropheus zebra, Rhodes's chilo Chilotilapia rhoadesii, Malawi eyebiter Dimidiochromis compressiceps, brown discus Symphysodon aequifasciatus, deep-water hap Haplochromis electra, electric blue hap Sciaenochromis fryeri, blue-white labido Labidochromis caeruleus, Placidochromis milomo and Frontosa cichlid Cyphotilapia frontosa were used as samples for study by PCR and ISH (Table 1). The disease had been tentatively diagnosed as FLB infection by cytological and histopathological examinations. Samples from 3 FLBfree firebird A. rubescens, as diagnosed by PCR and ISH, were selected as negative controls.

Tissue processing. Brain, eye, gill arch, kidney, spleen, liver, heart and gastrointestinal (GI) tract were removed and cut into small pieces of $\sim 5 \mathrm{~mm}^{3}$, and placed into neutral buffered formalin solution $(20: 1[\mathrm{v} / \mathrm{v}]$ ratio of fixative to tissue) for $16 \mathrm{~h}$. The fixed samples were dehydrated through an alcohol series and embedded in paraffin according to standard laboratory procedures. Serial sections $4 \mu \mathrm{m}$ thick were cut, floated on the surface of a water-bath and mounted on positively charged slides (Muto Pure Chemicals) for ISH assay.

Ultrastructure study. Ultrathin sectioning was performed as described by Mauel et al. (2003). Areas with lesions were removed from paraffin-embedded tissues, freed from paraffin with xylene and rehydrated via a graded series of alcohol into $0.01 \mathrm{M}$ sodium potassium phosphate buffer $(\mathrm{pH}$ 7.4). The samples were then fixed in $1 \%(\mathrm{w} / \mathrm{v})$ osmium in sodium potassium phosphate buffer, dehydrated via a graded series of alcohol and impregnated with Spurr's epoxy resin via propylene oxide. The samples were then sectioned and stained with uranyl acetate and Reynold's lead citrate for examination with a Hitachi H-600 transmission electron microscope.

DNA extraction. Areas with lesions removed from paraffin-embedded tissues, freed from paraffin with xylene and rehydrated via a graded series of alcohol into sodium potassium phosphate buffer ( $\mathrm{pH} 7.4$ ) were chosen as the initial targets for 16S rDNA amplification because bacteria were abundant in hematoxylin and eosin (H\&E)-stained sections. Samples were frozen in liquid nitrogen, then ground to a powder. The DNA samples were extracted using the DNeasy tissue kit (Qiagen) according to the manufacturer's instructions. DNA was finally eluted with $50 \mu \mathrm{l}$ of TE (10 mM Tris$\mathrm{HCl}\left[\mathrm{pH}\right.$ 7.4], $1 \mathrm{mM}$ EDTA) buffer and stored at $-20^{\circ} \mathrm{C}$.

Polymerase chain reaction. The FLB-specific primers were designed by comparing 12 previously published sequences (GenBank Accession Nos. AF206675, AF385857, AY928388 to AY928393 and DQ007453 to DQ007456) (Hsieh et al. 2007). The sequences of the individual primers were FLB16S180f: 5'-GCG-GATTAA-AGG-TGG-CCT-TTG-C-3' (forward primer) and FLB16S465r: 5'-CCT-GCA-AGC-TAT-TAA-CTC-ACAGG-3' (reverse primer). PCR amplification consisted of 35 cycles of denaturation at $94^{\circ} \mathrm{C}$ for $30 \mathrm{~s}$, annealing at $58^{\circ} \mathrm{C}$ for $30 \mathrm{~s}$ and extension at $72^{\circ} \mathrm{C}$ for $30 \mathrm{~s}$. A target fragment of $286 \mathrm{bp}$ for the FLB 16S rRNA gene (base pairs 180 to 485) was amplified. Then, $5 \mu \mathrm{l}$ of PCR product was electrophoresed in a $1.5 \%(\mathrm{w} / \mathrm{v})$ agarose gel, stained with ethidium bromide and photographed.

Cloning, sequencing and phylogenetic reconstructions. Following purification (QIAquick Spin columns, Qiagen), PCR products were cloned into a T vector using a TA cloning kit (YT\&A; Yeastern Biotech) according to the manufacturer's instructions, and sequenced using a 373A automatic sequencer and a BigDye Terminator cycle sequencing kit (Mission Biotech). Both strands were sequenced as a crosscheck, and compared with existing sequences in GenBank. Phylogenetic analysis was performed using the program MegAlign in the DNASTAR software (Doggett \& Blattner 1986). The Lasergene program (Version 5.0; DNASTAR) was used for sequence assembly and alignment. Multiplesequence alignments of both $16 \mathrm{~S}$ strands ( $286 \mathrm{bp}$ ) were compared using the Clustal W method (Thompson et al. 1994).

Synthesis of digoxigenin-labeled probe for ISH by PCR. The total genomic DNA was extracted from FLB Strain AF03-28, isolated from tilapia (Hsieh et al. 2006). The DIG-labeled FLB 16S rRNA gene probe was generated with the PCR DIG Probe Synthesis Kit (Roche Molecular Biochemicals) following the manufacturer's instructions. Briefly, a $0.5 \mathrm{ml}$ reaction tube contained the following reagents: PCR buffer $(10 \mathrm{mM}$ Tris- $\mathrm{HCl}[\mathrm{pH}$ 7.4], $50 \mathrm{mM} \mathrm{KCl}, 2.5 \mathrm{mM} \mathrm{MgCl}_{2}$ ), a ratio of DIG-11-deoxyuridine triphosphate (dUTP) to dTTP of 1:2 (200 $\mu \mathrm{M}$ PCR DIG Probe Synthesis Mix, Roche Diagnostic), each forward and reverse primer at $0.5 \mu \mathrm{M}, 1.5 \mathrm{U}$ of Taq DNA polymerase (Roche), $100 \mathrm{pg}$ of plasmid template, and distilled water to a final volume of $50 \mu$ l. The PCR was carried out with 35 cycles of $94^{\circ} \mathrm{C}$ for $30 \mathrm{~s}$, annealing at 


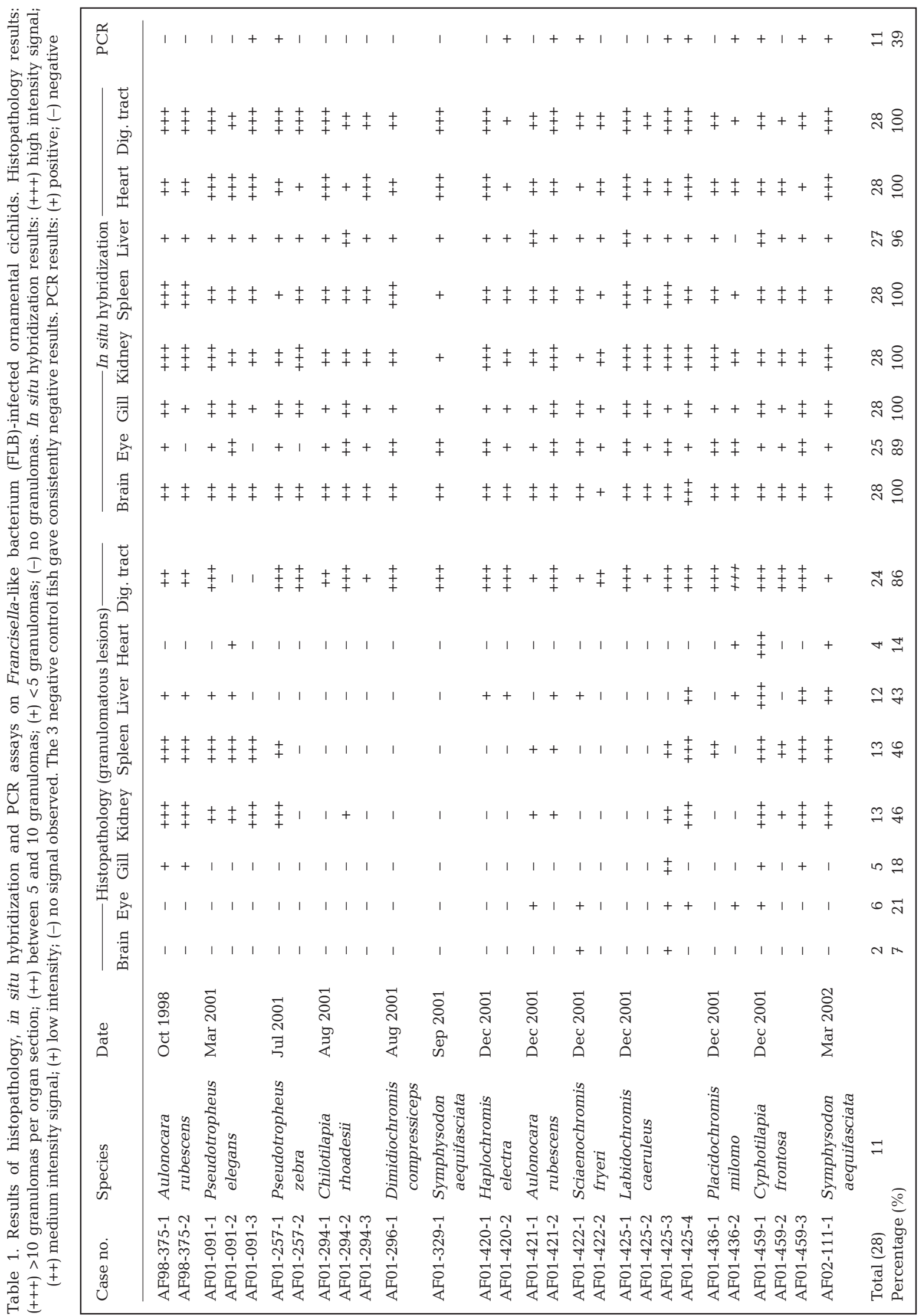


$58^{\circ} \mathrm{C}$ for $30 \mathrm{~s}$ and extension at $72^{\circ} \mathrm{C}$ for $30 \mathrm{~s}$. The resulting DIG-labeled probes were quantified further with DIG Quantitation test strips following the manufacturer's instructions (Roche Diagnostic).

In situ hybridization. Non-radioactive ISH was a standardized protocol (Teifke et al. 1994), modified as described by Hsieh et al. (2006). Briefly, proteolytic digestion of tissue sections was carried out with $10 \mathrm{mg}$ $\mathrm{ml}^{-1}$ of Proteinase K (Roche) in $50 \mathrm{mM}$ Tris- $\mathrm{HCl}$ ( $\mathrm{pH} 7.4$ ) for $15 \mathrm{~min}$ at $37^{\circ} \mathrm{C}$. For ISH, a 1:50 dilution of the PCR product was applied directly as a probe (200 ng digoxigenin-labeled probe $\mathrm{ml}^{-1}$ ). Tissue sections were counterstained briefly with methyl green (Sigma).

\section{RESULTS}

Gross findings and cytological examinations. At necropsy, most of the infected fish had multiple nodules in the visceral organs, especially in the kidney and spleen (Fig. 1, Table 1). A few fish had protruding eyes and skin ulceration lesions. Large amounts of Gram-negative coccobacilli were found intracellularly stained from the kidney and spleen smears.

Ultrastructural study. Examination with a transmission electron microscope revealed that the intracellular organisms were extremely irregular and pleomorphic in shape, with a size of $1.45 \pm 0.35 \mu \mathrm{m} \times 0.35 \pm 0.15 \mu \mathrm{m}$, and were within the cytoplasmic vacuoles of phagocytes (Fig. 2).

Molecular diagnosis. After PCR amplification using primer pair FLB16S180f/FLB16S465r, a fragment of approximately 286 base pairs (bp) was obtained from 11 infected fish (Fig. 3).

Phylogenetic analysis. The partial 16S rRNA gene sequences were determined for our 11 isolates and submitted to the GenBank database under Accession Numbers EF062346 to EF062356, respectively. The identities between the 11 FLB strains from cichlid ornamental fishes were $100 \%$, and they were closely related to other Taiwanese strains (AY928388 to AY928393 and DQ007453 to DQ007456) from tilapia (Hsieh et al. 2006) (Fig. 4).

In situ hybridization. Hybridization of the probe to the paraffin-embedded sections of fish tissue infected with FLB yielded strong color development. There was no hybridization to tissue from uninfected fish. Hybridization signals were observed as purple precipitates in target tissues, indicating binding of the labeled

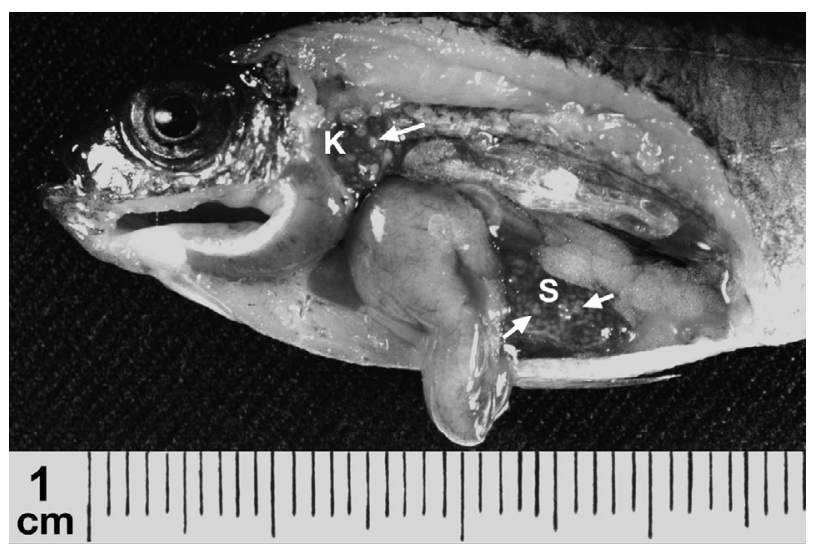

Fig. 1. Francisella-like bacterium (FLB)-infected ornamental fish (firebird Aulonocara rubescens) show white nodules (arrows) of various sizes in the enlarged kidney (K) and spleen (S)

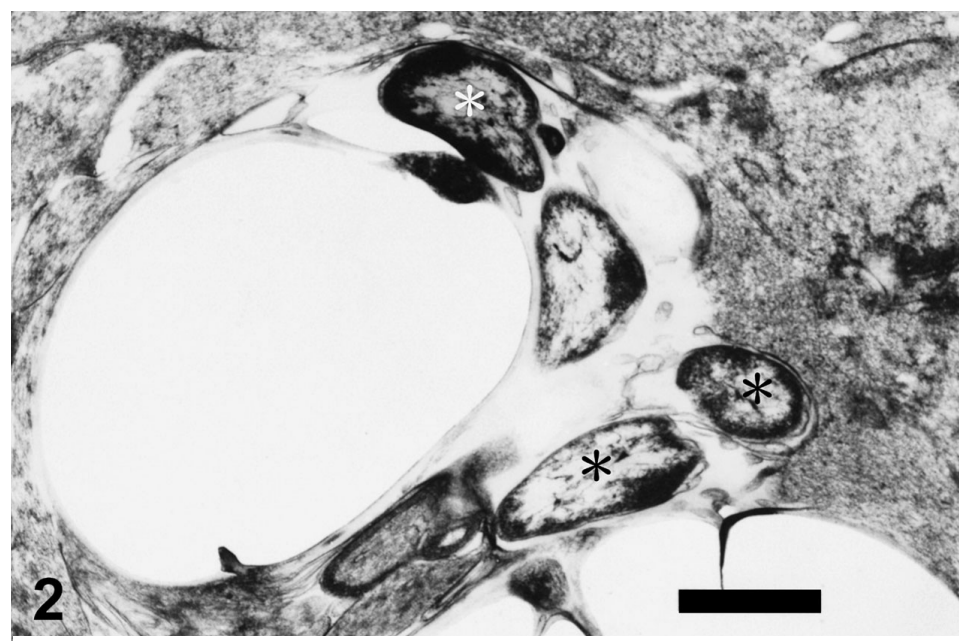

Fig. 2. Ultrastructural examination of the kidney. Francisella-like bacterium (*) is extremely irregular and pleomorphic in shape, $1.45 \pm$ $0.35 \mu \mathrm{m} \times 0.35 \pm 0.15 \mu \mathrm{m}$ in size, and appears within the cytoplasmic vacuoles of a phagocyte. Scale bar $=1 \mu \mathrm{m}$

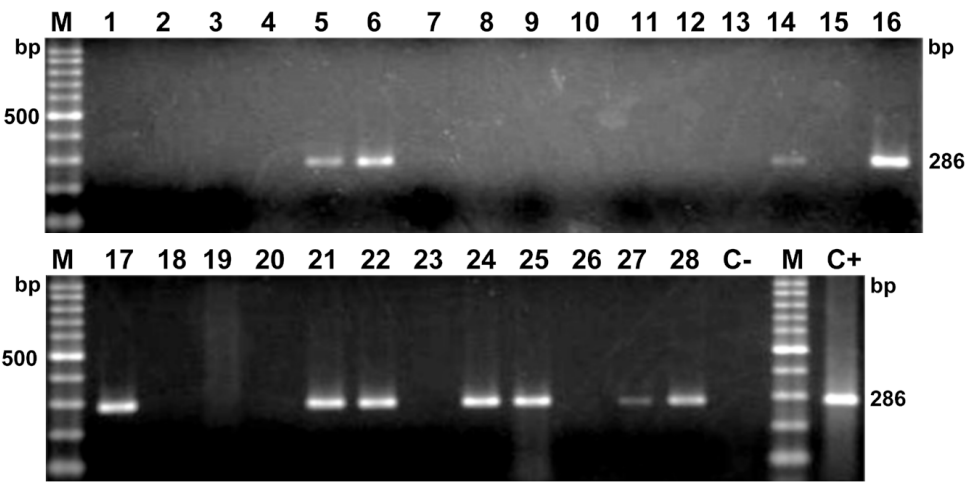

Fig. 3. An agarose electrophoresis gel stained with ethidium bromide showing PCR results for Francisella-like bacterium (FLB)-specific primers using genomic DNA of 28 archived samples as a template. A specific fragment of about $286 \mathrm{bp}$ of the FLB 16S rRNA gene is amplified by PCR. Lanes: M: 100 bp ladder marker; 1 to 28: infected fish Nos. 1 to 28, same order as given in Table 1 ; $\mathrm{C}-$ : negative control; $\mathrm{C}+$ : positive control (genomic DNA of FLB Strain AF03-28 isolated from tilapia) 


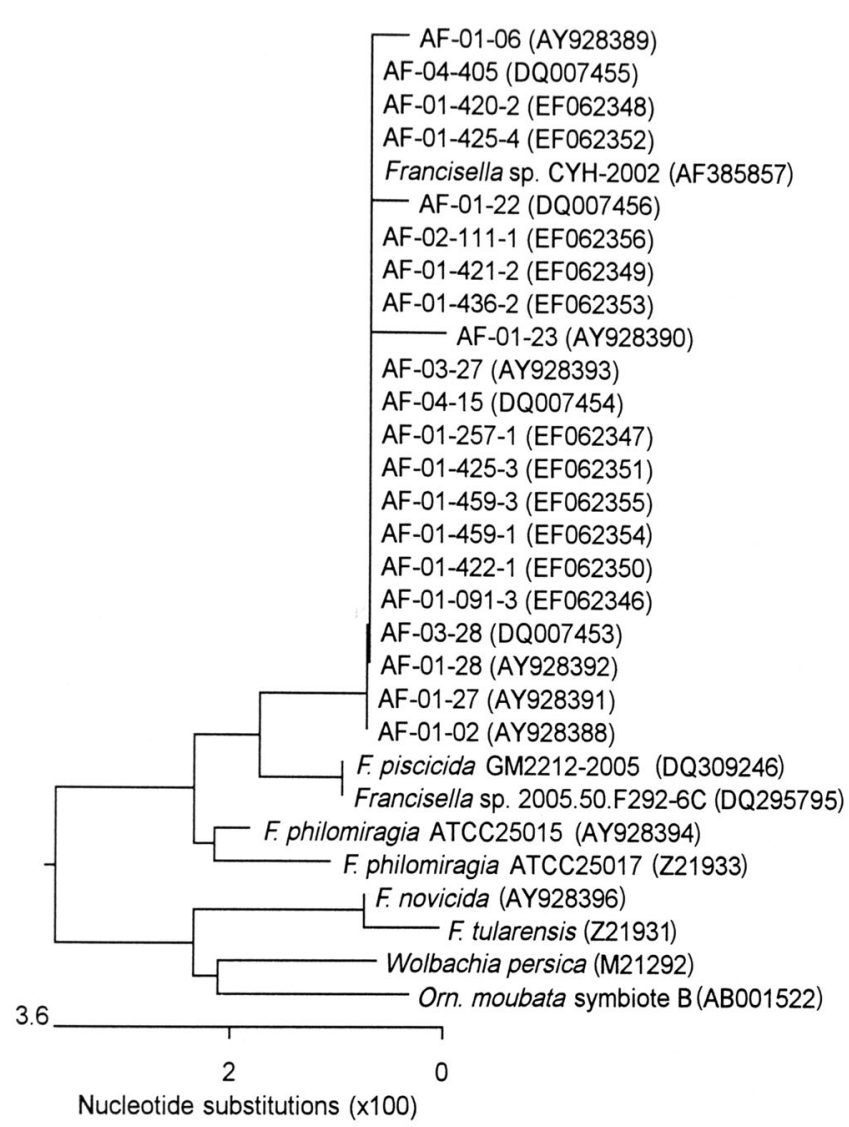

Fig. 4. Phylogenetic tree based on nucleotide sequences (286 bp) between Positions 180 and 465 of the partial 16S rDNA gene for Francisella-like bacteria. The tree was constructed using the Clustal W method, with the weighted residue weight table of DNASTAR software

probe to FLB DNA. The results of in situ hybridization are summarized in Table 1. Positive hybridization signals were observed in tissues of kidney, spleen, GI tract, heart, brain and gills in all the FLB-infected fish. The strongest signals were observed in the kidney, heart and GI tract (Fig. 5a-d). The brain and gills exhibited intermediate hybridization signals (Fig. 5e-g), and the weakest signals were occasionally seen in the liver (Fig. 5h). The locations of hybridization were detected mainly in macrophage-like cells, including the foamy, epithelioid and endothelial cells.

\section{DISCUSSION}

The agent causing systemic granulomas in tilapia in Taiwan has been identified as a member of the genus Francisella on the basis of sequence analysis of the $16 \mathrm{~S}$ rRNA gene. FLB is more fastidious than other Francisella species in culture, due to the requirement for a high concentration of cysteine for growth (Hsieh et al.
2006). Moreover, antibiotic therapy and secondary bacterial infections (e.g. Streptococcus spp. and Aeromonas spp.) are the main causes of interference with the isolation of FLB from infected fish. Histopathological examination is a routine diagnostic method but unfortunately the visceral granulomas of FLB infection are not unique in appearance. The morphological features are easy to confuse with other infections, such as mycobacteriosis, nocardiosis and fungal infections. FLB was provisionally called a 'rickettsia-like organism' (RLO) and causes extensive natural infections of all tilapia species (Chen et al. 1994, Chen \& Chao 1994), but is not pathogenic to ornamental cichlid, except Cichlasona managuense (Chen \& Chao 1994).

For the present study, we developed a non-radioactive DNA probe that could detect FLB natural infections in sections of tissue from ornamental fish made from formalin-fixed, paraffin-embedded samples. There was marked variation between the 3 methods used to detect FLB. Generally, ISH (correct identification 96 to $100 \%$ ) was more sensitive than PCR (39\%) and histopathological assays ( 7 to $86 \%$ ) (Table 1 ).

In this study, the hybridization signals were obtained mostly from visceral organs, including kidney, spleen, heart, digestive tract, gill and brain (Table 1). No hybridization signal was obtained in the eye or the liver of the 4 fish tested. This might be due to the different infection stages or to the small number of bacterial particles that were present in these naturally infected fish because the threshold for detection is 20 copies of the gene of interest (Komminoth \& Werner 1997). The DNA probe used for detection of FLB in tilapia has been used successfully to detect the agent causing visceral granulomas in ornamental fish. The partial 16S rDNA gene sequences (286 nt) from all our samples were identical and showed 99.3 to $100 \%$ similarity to other FLB Taiwanese strains from Oreochromis spp. (Hsieh et al. 2006). However, there was only $98.3 \%$ identity in comparison with 2 Norwegian strains of Atlantic cod Gadus morhua (DQ295795, Olsen et al. 2006; DQ309246, Nylund et al. 2006), showing 5 nucleotide differences (0 insertions, 5 substitutions). Based on the phylogenetic analysis, the causative agent may be the same or closely related to the pathogen inducing systemic granulomas in tilapia, but slightly different from the Norwegian isolates (Fig. 4).

PCR is a very sensitive method for the detection of FLB in tilapia (Hsieh et al. 2006). In general, the PCR assay is effective in detecting FLB in acute and subacute infections, where a large number of bacterial particles might still be present (Fig. 5a). However, it is not as sensitive in advanced cases (Fig. 5b). In our specimens, ISH was far superior to PCR, probably reflecting a smaller number of bacterial particles, dam- 


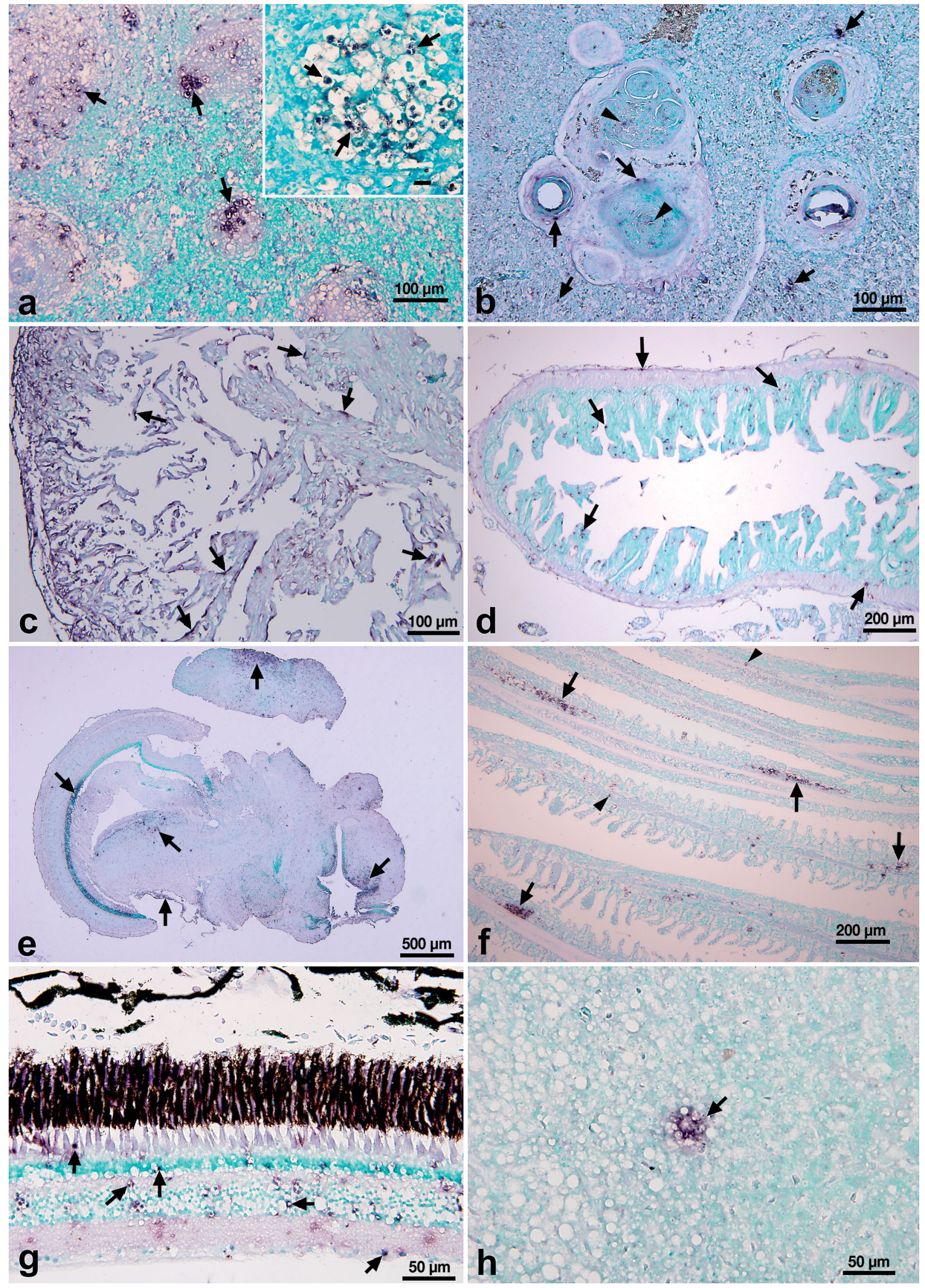


Fig. 5. In situ hybridization results from serial sections of the various organs in the infected fish. (a) Kidney. Strong hybridization signals are evident in the foamy cells and fixed macrophages (arrows). Inset: Abundant hybridization signals (arrows) appeared mainly in the cytoplasm of foamy cells. Scale bar $=10$ $\mu \mathrm{m}$. (b) Kidney. Hybridization signals are evident in phagocytes neighboring the granulomas and occur diffusely in the cytoplasm and in the interstitium (arrows). Only a few signals are in the centers (arrowheads). (c) Heart. Hybridization signals are evident in endothelial cells (arrows) of endocardium. (d) Intestines. Signals appear in phagocytes of the mucosa, submucosa and serosa (arrows). (e) Brain. Intermediate hybridization signals are in the optic lobe, the cerebellum and the meninges (arrows). (f) Gills. Signals in the secondary lamella (arrows) and hemocytes of the blood vessels (arrowheads). (g) Eyes. Signals in the phagocytes (arrows) and scattered throughout the retina. (h) Liver. Weak signals in the sinusoid epithelial cells (arrows), but the granulomas are absent. Scale bar $=(\mathrm{a}-\mathrm{c}) 100 \mu \mathrm{m},(\mathrm{d}, \mathrm{f})$ $200 \mu \mathrm{m}$, (e) $500 \mu \mathrm{m},(\mathrm{g}, \mathrm{h}) 50 \mu \mathrm{m}$

aged DNA, and/or degradation by the formalin fixative. Although PCR targeting FLB nucleic acids can offer a diagnostic tool of high specificity and sensitivity (Hsieh et al. 2006, 2007), this method does not provide any information with regard to the relation between the agent and the lesions. ISH is useful for identifying and locating the target agent in tissue sections with high levels of specificity and sensitivity.

A non-radioactive DIG-labeled DNA probe facilitates the transfer of this methodology to diagnostic laboratories. It can be used to screen archived samples for epidemiological investigations. Such studies will provide important information on the diagnosis, origin and distribution of FLB in freshwater ornamental fish. Our results show that, on the basis of histological and ISH examinations, the digestive tract may be the primary entry organ and transmission of FLB is suggested to be by the oral-fecal route. In addition, the gills may provide another route of infection, but further study is needed.

To our knowledge, the distribution of FLB in fish tissue has not been studied. We used the ISH method to study FLB in fish; this provided the first evidence that the bacteria existed in the various organs of ornamental fish, particularly in the fixed and the wandering macrophages. Investigations of bacterial metabolites and studies of bacterial colonization in other fish will yield more knowledge concerning the pathogenicity of the microbes. In this study, we screened archived samples (taken between 1998 and 2002) from STAADDC for FLB infections using histopathological, PCR and ISH examinations, and the results showed that all of the 11 fish species found to be infected (Table 1) belong to the Cichlidae family. Therefore, we suggested that ornamental cichlids might be more susceptible to FLB than other species. On the basis of our pre- vious and present studies, FLB is a major pathogen, causing visceral granulomas in freshwater farmed tilapia and in ornamental cichlids.

\section{LITERATURE CITED}

Barrett DM, Faigel DO, Metz DC, Montone K, Furth EE (1997) In situ hybridization for Helicobacter pylori in gastric mucosal biopsy specimens: quantitative evaluation of test performance in comparison with the CLO test and thiazine stain. J Clin Lab Anal 11:374-379

Bashir MS, Lewis FA, Quirke P, Lee A, Dixon MF (1994) In situ hybridization for the identification of Helicobacter pylori in paraffin wax embedded tissue. J Clin Pathol 47:862-864

Brown C (1998) In situ hybridization with riboprobes: an overview for veterinary pathologists. Vet Pathol 35:159-167

Campbell LA, Patton DL, Moore DE, Cappuccio AL, Mueller BA, Wang SP (1993) Detection of Chlamydia trachomatis deoxyribonucleic acid in women with tubal infertility. Fertil Steril 59:45-50

Chae JS, Kim MS, Madigan J (2002) Detection of Neorickettsia (Ehrlichia) in tissues of mice experimentally infected with cercariae of trematodes by in situ hybridization. Vet Microbiol 88:233-243

Chen RS, Chao CB (1994) Outbreak of a disease caused by rickettsia-like organism in cultured tilapias in Taiwan. Fish Pathol 29:61-7

Chen SC, Tung MC, Chen SP, Tsai JF, Wang PC, Chen RS, Lin SC, Adams A (1994) Systematic granulomas caused by a rickettsia-like organism in Nile tilapia, Oreochronuics niloticus (L.), from southern Taiwan. J Fish Dis 17:591-599

Doggett PE, Blattner FR (1986) Personal access to sequence databases on personal computers. Nucleic Acids Res 14: 611-619

Gebhart CJ, McOrist S, Lawson GHK, Collins JE, Ward GE (1994) Specific in situ hybridization of the intracellular organism of porcine proliferative enteropathy. Vet Pathol 31:462-467

Gencay M (1997) Chlamydia trachomatis detected in human placenta. J Clin Pathol 50:852-855

Gumus B, Sengil AZ, Solak M, Fistik T, Alibey E, Cakmak EA, Yeter M (1997) Evaluation of non-invasive clinical samples in chronic Chlamydial prostatitis by using in situ hybridization. Stand J Ural Nephrol 31:449-451

Hayashi Y, Watanabe J, Nakata K, Fukayama M, Ikeda H (1990) A novel diagnostic method of Pneumocystis carinii. In situ hybridization of ribosomal ribonucleic acid with biotinylated oligonucleotide probes. Lab Invest 63:576-580

Hsieh CY, Tung MC, Tu C, Chang CD, Tsai SS (2006) Enzootics of visceral granulomas associated with Francisella-like organism infection in tilapia (Oreochromis spp.). Aquaculture 254:129-138

Hsieh CY, Tung MC, Liu HJ, Tsai SS (2007) Isolation and identification of a new fish pathogen, Francisella-like bacterium (FLB) causing systemic granulomas in tilapias. $\mathrm{J}$ Fish Dis (in press)

Hulten $K$, Karttunen TJ, El-Zimaity HMT, Naser SA, Almashhrawi A, Graham DY, El-Zaatari FAK (2000) In situ hybridization method for studies of cell wall deficient M. paratuberculosis in tissue samples. Vet Microbiol 77: 513-518

Jantos CA, Nesseler A, Waas W, Baumgartner W, Tillmanns H, Haberbosch W (1999) Low prevalence of Chlamydia pneumoniae in atherectomy specimens from patients with coronary heart disease. Clin Infect Dis 28:988-992 
Komminoth P, Werner M (1997) Target and signal amplification: approaches to increase the sensitivity of in situ hybridization. Histochem Cell Biol 108:325-333

Kwon D, Chae C (1999) Detection and localization of Mycoplasma hyopneumoniae DNA in lungs from naturally infected pigs by in situ hybridization using a digoxigenin labeled probe. Vet Pathol 36:308-313

Lewis FA, Wells M (1992) Detection of virus in infected human tissue by in situ hybridization. In: Wilkinson DG (ed) In situ hybridization: a practical approach. Oxford University Press, Oxford, p 125-136

Loy JK, Dewhirst FE, Weber W, Frelier PF, Garbar TL, Tasca SI, Templeton JW (1996) Molecular phylogeny and in situ detection of the etiologic agent of necrotizing hepatopancreatitis in shrimp. Appl Environ Microbiol 62:3439-3445

Mauel MJ, Miller DL, Frazier K, Liggeet AD, Styer L, Montgomery-Brock D, Brock J (2003) Characterization of a piscirickettsiosis-like disease in Hawaiian tilapia. Dis Aquat Org 53:249-255

Editorial responsibility: David Bruno,

Aberdeen, UK
Nylund A, Ottem KF, Watanabe K, Karlsbakk E, Krossøy B (2006) Francisella sp. (family Francisellaceae) causing mortality in Norwegian cod (Gadus morhua) farming. Arch Microbiol 185:383-392

Olsen AB, Mikalsen J, Rode M, Alfjorden A, Hoel E, StraumLie K, Haldorsen R, Colquhoun DJ (2006) A novel systemic granulomatous inflammatory disease in farmed Atlantic cod, Gadus morhua L., associated with a bacterium belonging to the genus Francisella. J Fish Dis 29:307-311

Teifke JP, Hardt M, Weiss E (1994) Detection of bovine papillomavirus DNA in formalin-fixed and paraffinembedded equine sarcoids by polymerase chain reaction and non-radioactive in situ hybridization. Eur $\mathrm{J}$ Vet Pathol 1:5-10

Thompson JD, Higgins DG, Gibson TJ (1994) CLUSTAL W: improving the sensitivity of progressive multiple sequence alignment through sequence weighting, position specific gap penalties and weight matrix choice. Nucleic Acids Res 22:4673-4680

Submitted: June 18, 2006; Accepted: October 31, 2006 Proofs received from author(s): March 21, 2007 